\title{
Service Learning: Mengintegrasikan Tujuan Akademik Dan Pendidikan Karakter Peserta Didik Melalui Pengabdian Kepada Masyarakat
}

\author{
Endah Setyowati, Alviani Permata \\ Koordinatorat Mata Kuliah Humaniora, Universitas Kristen Duta Wacana \\ Pos-el: esetyowati@staff.ukdw.ac.id \\ Pos-el: alviani@staff.ukdw.ac.id
}

\begin{abstract}
Service learning is a teaching approach that combines academic goals and the character education through community service activities. Teaching strategies through knowledge, experiences, and reflections applied in an interdiciplinary course provide opportunities for students to relate knowledge directly from the classroom to community problems with their participation as volunteers in a specified community. The community which is chosen as a target group was fitted to the lecture materials which emphasized on issues of state discrimination against vulnerable groups and impacts of decreasing environmental quality on sustainable peace. The learning outcomes which is set at level of students' awareness of social problems are measured by changes in perceptions of issues faced by target groups before and after students doing a community service through periodic journal reports.
\end{abstract}

Keywords: service learning, community service, assisted community, periodic jurnal

\begin{abstract}
Abstrak
Service learning adalah sebuah pendekatan pengajaran yang menggabungkan antara tujuan akademik dan pendidikan karakter peserta didik melalui kegiatan pengabdian kepada masyarakat. Strategi pengajaran melalui pengetahuan, pengalaman, dan refleksi diterapkan dalam mata kuliah yang bersifat lintas bidang dan memberikan peluang bagi peserta didik untuk merelasikan pengetahuan di kelas dengan problem komunitas secara langsung, dengan partisipasinya sebagai relawan di komunitas yang ditentukan. Komunitas yang dipilih pun disesuaikan dengan materi kuliah yang menekankan pada isu diskriminasi negara terhadap kelompok rentan dan dampak penurunan kualitas lingkungan hidup terhadap perdamaian berkelanjutan. Adapun capaian pembelajaran yang ditetapkan pada aras penyadaran peserta didik terhadap problem sosial diukur dari perubahan persepsi atas isu yang dihadapi kelompok sasaran sebelum dan sesudah mahasiswa atau peserta didik melakukan pengabdian kepada masyarakat melalui laporan jurnal berkala.
\end{abstract}

Kata kunci: service learning, komunitas dampingan, jurnal berkala 


\section{Pengantar}

Service learning adalah salah satu pendekatan dalam pengajaran yang menggabungkan tujuan akademik dan upaya menumbuhkan kesadaran dalam memecahkan persoalan masyarakat secara langsung. Sebagai pendekatan, Gerholz membedakan service learning (belajar melakukan pengabdian masyarakat) dengan community service (pengabdian kepada masyarakat). Artinya, dalam pengabdian kepada masyarakat, mahasiswa juga melakukan kegiatan di tengah-tengah masyarakat, namun tidak terkait khusus dengan pengajaran sebuah mata kuliah tertentu (2018:48). Sementara itu, service learning dilaksanakan sebagai "praktikum sosial" dari sebuah mata kuliah dalam rangka mengembangkan keterampilan sebagai warga negara (Brown via Bridwell, 2013:186).

Koordinatorat Mata Kuliah Humaniora (MKH) Universitas Kristen Duta Wacana mulai mengembangkan mata kuliah pilihan dengan pendekatan service learning sejak tahun ajaran 2011-2012 dalam mata kuliah Pendidikan Perdamaian dan Pendidikan HAM dan Demokrasi. Evaluasi terus menerus dilakukan sejak tahun ajaran 2016 menyangkut bentuk, materi, dan cara evaluasi capaian pembelajaran terhadap pelaksanaan mata kuliah berpraktikum dengan pendekatan service learning. Hal ini tampak sejajar dengan tujuan yang diuraikan dalam Standar Nasional Pendidikan Tinggi, yaitu "penting untuk mempertimbangkan proses pembelajaran yang mencakup karakteristik, perencanaan, pelaksanaan proses pembelajaran suatu mata kuliah dengan beban mengajar mahasiswa." Dengan demikian, dalam rangka meningkatkan pemahaman dan penguasaan peserta didik dalam menangkap pengetahuan yang diberikan melalui proses pembelajaran, seorang pengajar perlu menggunakan pendekatan berbasis peserta didik atau studentbased learning yang mengajak peserta didik untuk berpatisipasi aktif dalam proses pembelajaran. Berbagai bentuk kegiatan dalam pelaksanaan proses pembelajaran telah banyak dilakukan dan salah satunya adalah service learning.

Artikel ini akan menguraikan konsep dan praktik penerapan pendekatan service learning. Mata kuliah itu dirancang sebagai sebuah mata kuliah wajib pilihan yang bersifat lintas bidang karena diikuti oleh mahasiswa tahun pertama atau kedua yang berasal berbagai fakultas maupun program studi. Mahasiswa tahun pertama atau kedua merupakan subjek sasaran mata kuliah dengan tujuan mengembangkan kompetensi sosial mahasiswa sejak awal duduk di bangku kuliah.

\section{Konsep Service Learning}

Satu landasan teori untuk service learning diberikan oleh ahli pendidikan Amerika Serikat, David Kolb, dengan Experiential Learning Theory (1984). Dalam teori itu, Kolb percaya bahwa pengetahuan diciptakan melalui transformasi pengalaman. Dalam pandangan Kolb, gasasan atau pandangan seseorang dapat berubah ketika berada dalam sebuah setting tertentu. Jadi, konsep baru atau penemuan kembali gagasan yang pernah terbentuk sebelumnya melalui pembelajaran di kelas, hadir saat peserta didik terlibat dalam service learning. Service learning berakar dari gagasan Dewey bahwa tujuan pendidikan adalah menjadikan peserta didik sebagai warga negara yang aktif dan bertanggung jawab di

1 Standar Proses, Pasal 10 ayat 1. Standar Nasional Pendidikan Tinggi berdasarkan Permendikbud Nomor 49 tahun 2014. 
dalam masyarakat (Kolb, 1984; Kolb dan Kolb via Fleck et al., 2017:232-233).

Menurut Godfrey et al. (2005), tiga elemen pokok dalam service learning meliputi (1) realitas, (2) refleksi, dan (3) relasi yang bersifat timbal balik. Realitas berarti kebutuhan masyarakat harus nyata dan selaras dengan tujuan mata kuliah. Peserta didik juga dihadapkan pada problem sosial tertentu selama masa pengabdian masyarakat. Sebagai contoh adalah rendahnya kesadaran masyarakat atas permasalahan yang mereka hadapi, yang ditunjukkan dengan sikap tidak peduli atau sulit menerima gagasan baru. Sementara itu, refleksi adalah sarana mahasiswa untuk mengukur pengaruh kegiatan pengabdian kepada masyarakat terhadap pemberdayaan masyarakat dan pengembangan diri mahasiswa. Adapun relasi timbal balik adalah peserta didik dan masyarakat bekerja sama secara kooperatif dalam berkegiatan. Sekalipun kedua kelompok memiliki pemahaman dan pengalaman yang berbeda dari sudut konten pengajaran, namun hubungan timbalbalik dari kedua perspektif itu akan saling memberi kontribusi pada pembangunan masyarakat dan pengembangan kompetensi sosial-budaya peserta didik.

Lebih lanjut, Brown (2011) berpendapat bahwa timbal balik merupakan faktor penting yang mengarah pada keberhasilan berkelanjutan dari program service learning (Godfrey et al., 2005; Yorio dan Ye via Gerholz, 2018:48; Condon, 2015:197). Apabila terdapat kelompok pegiat masyarakat, misalnya LSM yang bekerja di kelompok pengabdian, mereka menjadi rekan kerja mahasiswa sehingga pada gilirannya akan terbantu

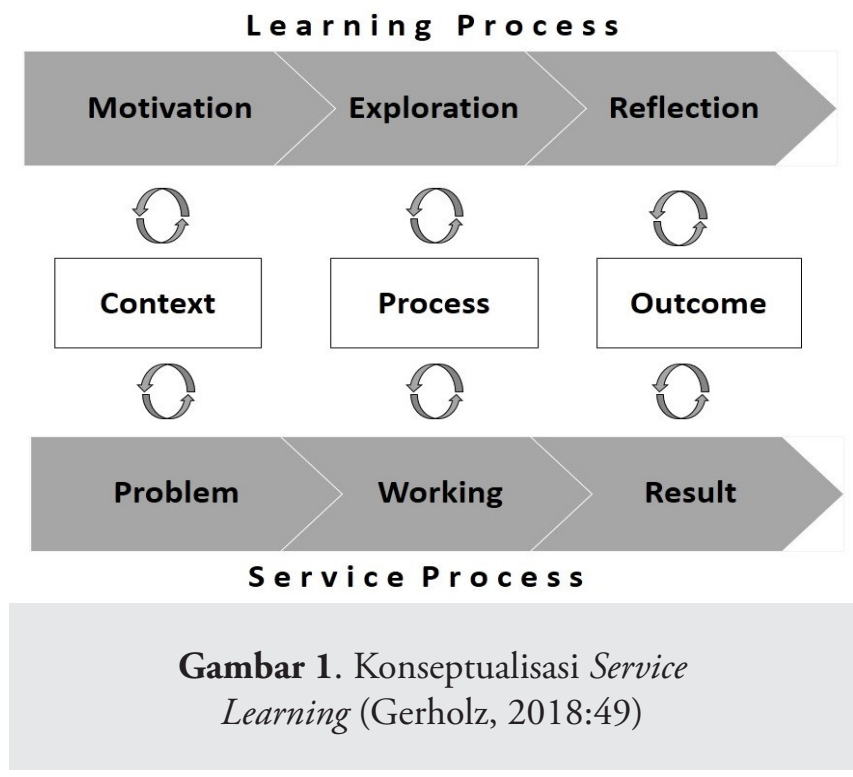
pula dalam mencapai visi dan misi organisasi LSM melalui karya mahasiswa. Bagi institusi perguruan tinggi, service learning memperlihatkan keterlibatan dalam mendorong kekuatan masyarakat sipil. ${ }^{2}$ Gambar di bawah ini memvisualisasikan proses service learning.

Robert Stigmon (via Fulco, 1996:2) memberikan tipologi service learning yang akan menentukan pilihan pencapaian mata kuliah yang dapat dijelaskan sebagai berikut.

1. Service-LEARNING: jika ditekankan pada kata learning, tujuan akademik sebagai tujuan utama sehingga hasil pengabdian adalah capaian sekunder.

2. SERVICE-Learning: jika ditekankan pada kata service, hasil pengabdian yang utama dan tujuan akademik adalah sekunder.

3. Service learning: jika tidak menekankan kedua kata, antara pengabdian dan tujuan akademik bersifat terpisah.

4. SERVICE-LEARNING: jika kedua kata ditulis tebal dan bertanda hubung, pengabdian dan tujuan akademik memilki bobot yang sama dan semua pihak saling

2 Starting Point Teaching Entry Geoscience, ” Why Use Service Learning?” https://serc.carleton. edu/introgeo/service/why.html diakses pada 1 Mei 2018. 
belajar dan saling meningkatkan performa pihak-pihak yang terlibat (mahasiswa, lembaga perguruan tinggi, organisasi masyarakat, dan masyarakat).

\section{Merancang Kegiatan Service Learning}

Pengajaran mata kuliah yang berisi konsep-konsep yang terkait konten mata kuliah akan dilaksanakan di ruang kelas dan dilanjutkan dengan praktikum dalam bentuk pengabdian kepada masyarakat. Seturut dengan itu, pengajar memerlukan landasan dalam perancangan mata kuliah dengan pendekatan service learning, yang meliputi:

1. Capaian pembelajaran, yang ditentukan dengan mengikuti format yang disarankan Stigmon, namun tetap menyesuaikan aras peserta kuliah. Sebagian besar peserta mata kuliah Pendidikan Perdamaian adalah mahasiswa tahun pertama atau tahun kedua. Oleh karena itu, tujuan pembelajaran didasarkan pada aras pertama atau kedua yang difokuskan pada hasil pengabdian, atau sebaliknya, hasil akademik semata sebagai capaian primer. Dalam mata kuliah Pendidikan Perdamaian, menumbuhkan sikap dan perilaku kerelawanan mahasiswa dipilih sebagai capaian primer sehingga refleksi pengalaman pelayanan kepada masyarakat menjadi evaluasi primer. Bagan di bawah ini dapat memperjelas perbedaan capaian-capaian yang diharapkan dari pendekatan service learning.

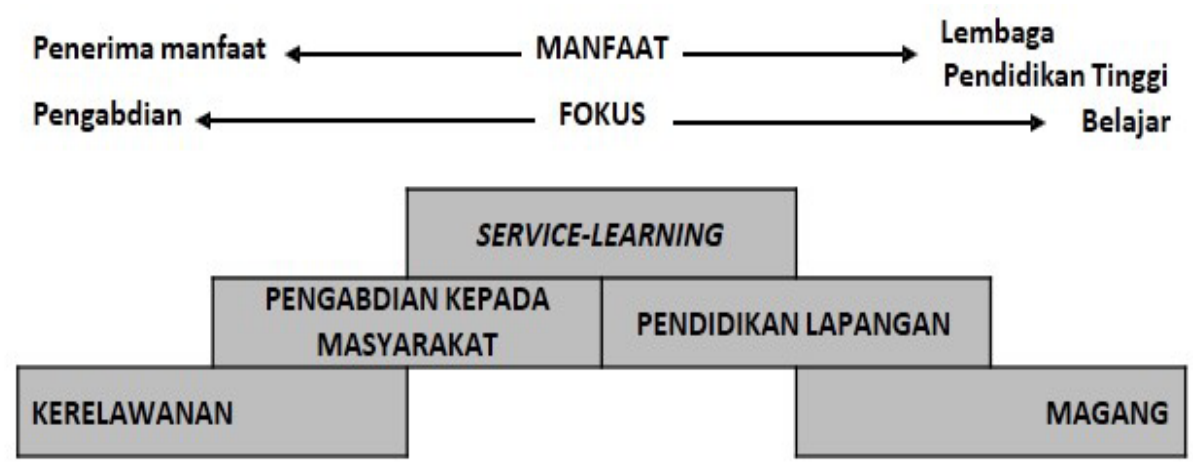

Gambar 2. Bagan Capaian Pendekatan Service Learning (Stigmon via Fulco, 1996:3)

2. Landasan perancangan mata kuliah. Mata kuliah Pendidikan Perdamain berpraktikum dirancang dengan mengacu pada peraturan mata kuliah berpraktikum yang dikeluarkan oleh peraturan DIKTI (2015). ${ }^{3}$ Bentuk dan materi pelayanan bergantung pada kebutuhan pihak yang memperoleh manfaat dari kerjasama pelayanan antara mahasiswa dan masyarakat.

3. Pengajar mengidentifikasi komunitas-komunitas yang dapat menjadi sasaran

3 Peraturan Menteri Riset, Teknologi, dan Pendidikan Tinggi Republik Indonesia Nomor 44 Tahun 2015 tentang Standar Nasional Pendidikan Tinggi (pasal 17) ayat 4: 1 sks pada proses pembelajaran berupa praktikum, praktik studio, praktik bengkel, praktik lapangan, penelitian, pengabdian kepada masyarakat, dan/atau proses pembelajaran lain yang sejenis, 170 (seratus tujuh puluh) menit per minggu per semester; Mata Kuliah Berpraktikum (1 SKS setara 14 x 170 Menit = 2.380 menit = 40 jam dalam satu semester. 
dari kegiatan praktikum mahasiswa berdasarkan tema, topik, dan materi kuliah selama satu semester.

4. Persiapan praktikum lapangan juga diperlukan sebagai bekal mahasiswa sebelum melakukan kerja pelayanan di masyarakat.

5. Nota kerja sama antarlembaga juga diperlukan sebagai landasan kerja sama dan dokumentasi kerja sama lembaga pendidikan tinggi dengan kelompok masyarakat. Hal ini dapat dikecualikan dengan mempertimbangan karakter oganisasi kelompok sasaran, mulai dari yang bersifat terbuka keanggotaannya hingga yang terlembaga secara formal.

6. Keterlibatan pengajar, baik sebagai pembimbing maupun partisipan di lapangan bersama mahasiswa.

7. Apabila dirinci, bentuk evaluasi dan rubriknya ${ }^{4}$ terdiri atas refleksi dalam bentuk jurnal; tes tertulis, observasi partisipasi dengan rubrik yang mengintegrasikan capaian akademik dan pengabdian oleh pengajar ataupun masyarakat yang menjadi sasaran pengabdian. Dalam hal ini, lembar evaluasi untuk masyarakat juga perlu dipersiapkan.

8. Dokumentasi bersifat audiovisual meskipun bersifat opsional, namun juga perlu dipertimbangkan untuk disesuaikan dengan minat para mahasiswa saat ini.

\section{Pelaksanaan Kegiatan Service Learning}

Pelaksanaan terakhir mata kuliah Pendidikan Perdamaian dengan pendekatan service learning adalah pada semester gasal tahun ajaran 2017-2018. Pelaksanaan meliputi tiga tahap. Kuliah tahap pertama dilaksanakan di ruang kelas dengan materi berisi konsep yang menjadi kajian bidang perdamaian, yang dilakukan dengan prinsip pengajaran berpusat pada peserta didik. Diskusi kelompok, analisis kasus, bertukar peran, atau simulasi menjadi strategi pengajaran dalam mempelajari konsep-konsep yang bersifat abstrak. Pengajaran di kelas dilaksanakan selama setengah semester atau sebanyak tujuh kali tatap muka. Masa Ujian Tengah Semester dimanfaatkan pengajar untuk memberikan pelatihan keterampilan khusus yang dibutuhkan dalam melaksanakan service learning di komunitas. Adapun pelatihan itu dilaksanakan selama satu hari yang terdiri atas empat sesi yang setara dengan empat kali tatap muka (@ 3 SKS). Sebagai contoh, MKH UKDW telah mengembangkan kemitraan dengan organisasi pegiat masyarakat yang bekerja pada penyadaran HAM atas kelompok-kelompok rentan perempuan lanjut usia (penyintas pelanggaran HAM). Oleh karena itu, topik persiapan praktikum yang diberikan adalah sensitivitas budaya, keterampilan komunikasi sebagai caregiver, dan menulis jurnal.

Sebelum perkuliahan dimulai, pengajar telah mengidentifikasi kelompok-kelompok komunitas yang relevan sebagai subjek sasaran mata kuliah. Dalam tahun ajaran itu, MKH UKDW menentukan empat komunitas, yakni:

1. ReISpirasi, sebuah kumpulan pegiat muda yang bekerja dalam penyelamatan lingkungan Pantai Samas yang rentan abrasi, limbah sampah, dengan strategi

4 Standar penilaian pembelajaran merupakan kriteria minimal tentang peniliaian proses dan hasil belajar mahasiswa dalam rangka pemenuhan capaian pembelajaran lulusan. Adapun prinsip peneliaian harus bersifat edukatif, otentik, objketif, akuntabel, transparan, dan dilakukan secara terintegrasi. 
penyelamatan penyu dan berkegiatan bersama anak-anak setempat;

2. Petani Tanaman Organik yang merupakan kumpulan mantan anak jalanan yang mengusahakan nafkah dengan bertani secara organik;

3. FOPPERHAM (Forum Pendidikan dan Perjuangan Hak Asasi Manusia) yang memfokuskan kegiatannya pada kelompok lanjut usia (lansia) penyintas Peristiwa 1965 ;

4. Komunitas Perkampungan Sosial Pingit yang dikoordinasi oleh para frater dari Kolosani Kota Baru. Komunitas ini memberikan kesempatan kepada para mahasiswa di Yogyakarta untuk menjadi relawan pendampingan kegiatan anak-anak dengan latar belakang orang tua sebagai pemulung yang tinggal sementara di Kampung Pingit, selain anak-anak penduduk tetap di Kampung Pingit.

Ada dua kategori komunitas yang dipilih, yakni 1) komunitas yang kegiatannya bersifat outdoor dan berkenaan langsung dengan isu penyelamatan atau pelestarian lingkungan dan 2) komunitas yang memfokuskan kegiatannya pada pendampingan kelompok rentan diskriminasi oleh negara ataupun lingkungan sosial. Dengan perbedaan kategori itu, bentuk dan karakter kegiatan yang dilakukan pun berbeda. Dengan perbedaan kategori komunitas, mahasiswa dapat memilih komunitas berdasarkan minat dan pertimbangan pribadi. Akan tetapi, pengajar juga mempertimbangkan keseimbangan jumlah mahasiswa dibandingkan dengan jumlah anggota komunitas atau luasnya cakupan kerja komunitas. Sebagai contoh, ketika mahasiswa menjadi relawan di komunitas Petani Organik atau ReISpirasi, mahasiswa tidak dituntut memiliki keahlian atau pengalaman tertentu karena bentuk kegiatannya adalah belajar dan bekerja secara langsung. Pendekatan "bekerja" dan mentoring oleh anggota komunitas pada umumnya paling diminati mahasiswa karena capaian setiap akhir kegiatan pun langsung dapat dirasakan.

Kegiatan mahasiswa di Komunitas Petani Organik dilakukan seminggu sekali pada Minggu sejak pukul 09.00-12.00. Langkah pertama, petani menjelaskan rencana kegiatan relawan pada hari itu dan jenis-jenis kegiatan yang akan dilakukan. Mahasiswa

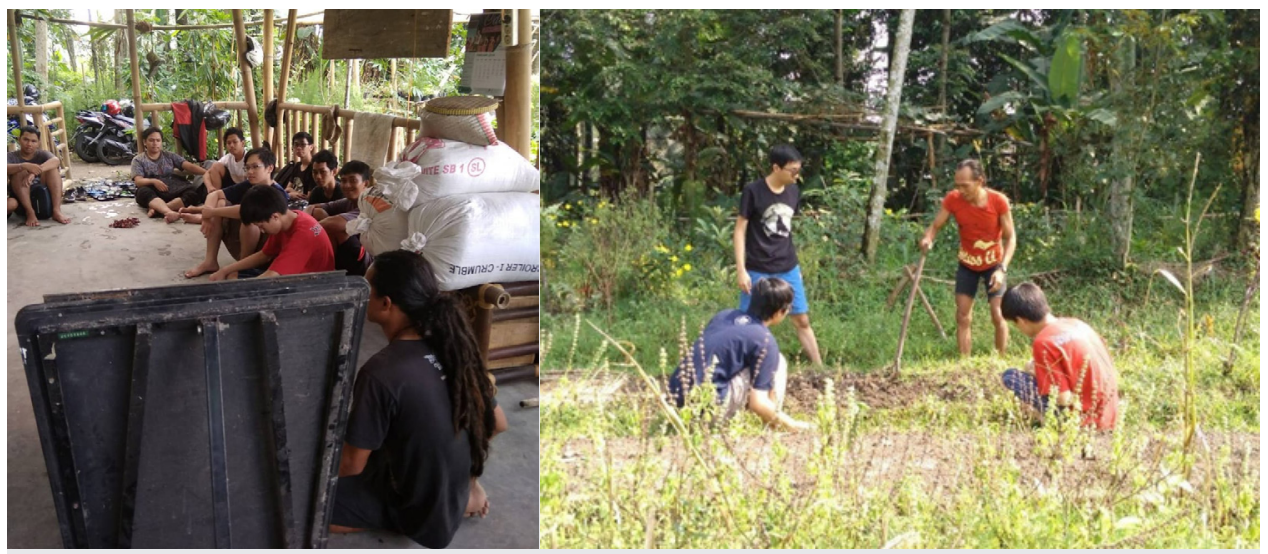

Gambar 3. Kegiatan di Komunitas Petani Organik 
dibagi menjadi beberapa kelompok yang akan bekerja secara bergilir. Setiap pekerjaan dilakukan selama 30 menit sehingga mahasiswa mendapat pengalaman menanam bibit, membersihkan tanaman dari gangguan binatang seperti keong dan sejenisnya, atau memanen, yang kesemuanya dilakukan petani dengan memberi contoh secara langsung. Selama berkegiatan, petani juga menjelaskan nama tanaman dalam bahasa lokal, karakter tanaman, pemasaran tanaman, hingga kehidupan sehari-hari. Pada akhir kegiatan, petani dan relawan mahasiswa melakukan evaluasi kegiatan serta tanya jawab.

Setiap mahasiswa yang terlibat memiliki jurnal harian sebagai catatan kegiatan yang akan dikumpulkan sebagai salah satu evaluasi mata kuliah. Jurnal harian pada umumnya berisi pengalaman yang memuat suasana kegiatan dan pembelajaran yang dipetik dari kegiatan tersebut. Misalnya, hambatan, kemajuan, informasi baru, atau kesadaran baru berkat berelasi dengan kelompok sasaran dan sesama relawan ataupun interaksi langsung dengan alam. Berikut ini adalah beberapa contoh pengalaman mahasiswa relawan di komunitas mantan anak jalanan yang menjadi petani organik.

Mas $S$ terampil sekali dalam bertanam dan pasarnya ternyata restoran yang banyak dikunjungi turis asing dan juga hotel-hotel besar. Kalau tidak laku baru dijual di pasar. Saya juga baru tahu jika Mas $S$ anggota punk karena melihat jaket dan sepatu pakunya juga tatonya. Saya tentu agak gentar dengan penampilan Mas $S$ dan kawankawannya. Awal Mas $S$ bertanam, orang datang menginjak-injak tanamannya. Polisi juga tanya-tanya apa yang ditanam, mungkin dikira menanam ganja. Sekarang banyak tetangga yang datang bertanya cara menanam pakai pupuk organik. Saya melihat pekerjaan petani itu tidak mudah, harus sabar dan telaten. Kita menjadi lebih menghargai apa yang dimakan karena itu (Jurnal 13 Mei 2018, mahasiswa FTI-2017).

Mahasiswa mendapat pengetahuan baru yang merelasikan fungsi dari jenis-jenis kegiatan alam dengan persoalan sosial di masyarakat.

Saya juga baru tahu tentang Pantai Samas yang menjadi tempat bertelurnya penyu dan juga fungsi penyu untuk kelestarian alam. Masyarakat di sini sudah sadar kalau penyu tidak boleh jadi barang dagangan. Saya kali ini mendapat jatah menanam pandan dan membersihkan kolam penyu. Tanaman itu mempunyai nama lokal

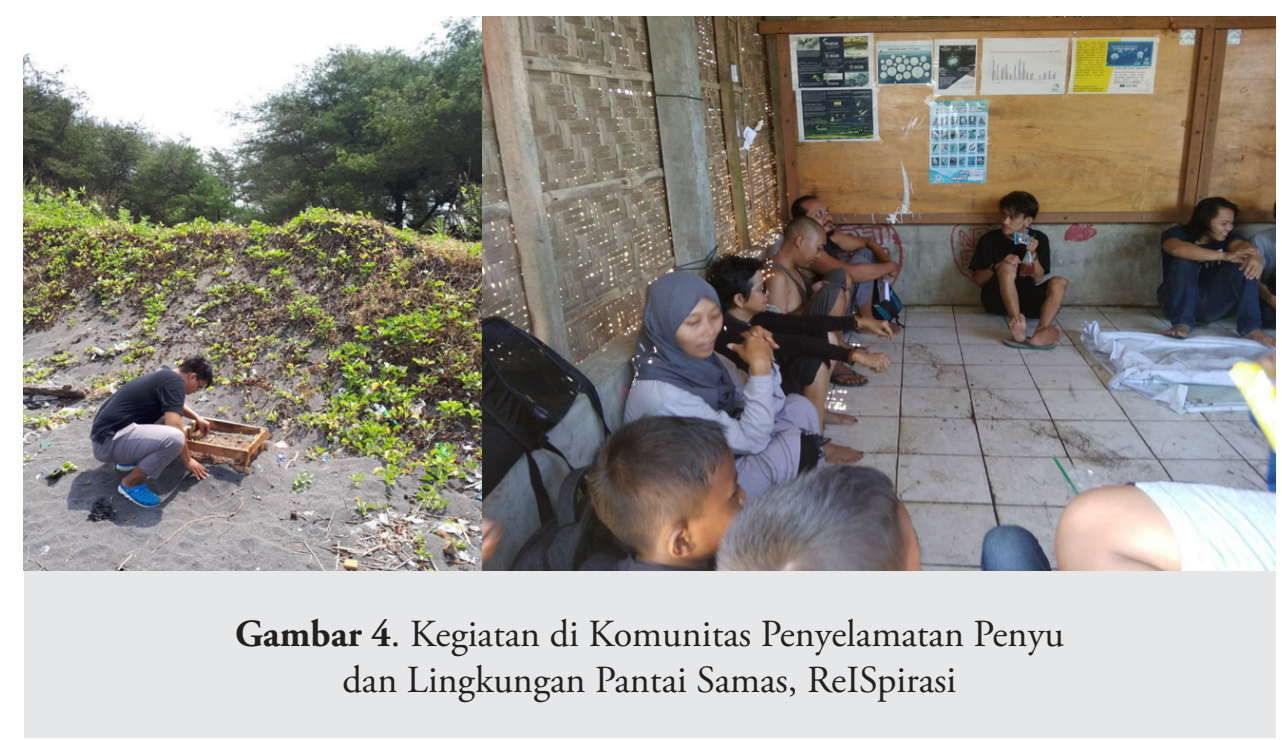


"Pandan Buto (buto: raksasa) atau pandan pantai. Kami bekerja sama. Ada yang menggali, ada yang membawa bibit, ada pula yang menanamnya. Tanaman ini dapat mengurangi dampak korosi bagi perumahan di tepi pantai, meningkatkan kelembaban pasir, dan melindungi penyu dari predator karena durinya tajam. Ada juga mahasiswa dari perguruan tinggi lain yang bekerja dengan anak-anak. Menurut kakak-kakak ReIspirasi itu penting karena anak-anak adalah kelak menjadi kelompok penyelamat lingkungan Pantai Samas ketika mereka dewasa dan tinggal di situ (Jurnal 22 April 2018, mahasiswa FTI-2017).

Pada komunitas yang bekerja dengan isu-isu HAM dengan memberdayakan kelompok termarjinalkan, mahasiswa mendapat persiapan khusus sebagai relawan oleh komunitas sebelum bekerja dengan kelompok sasaran. Hal ini karena seluruhnya telah berusia lanjut, namun tetap aktif melakukan aktivitas sehari-hari. Secara sosial, kelompok sasaran adalah kelompok yang mendapat stigma negatif oleh negara sehingga berpengaruh terhadap penerimaan masyarakat terhadap keberadaan mereka. Meski demikian, kegiatan yang dilakukan para penyintas Peristiwa 1965 adalah kegiatankegiatan yang juga dilakukan oleh masyarakat pada umumnya. Misalnya arisan, membentuk kelompok simpan pinjam, saling menjenguk apabila ada anggota yang sakit, bekumpul untuk sekadar bercengkerama, membaca buku, dan berlatih kesenian (tembang).

Salah satu program relawan yang diikuti oleh mahasiswa adalah One Week One Mother yang berbentuk aktivitas mengunjungi kelompok sasaran, khususnya perempuan lanjut usia minimal satu kali dalam seminggu. Tantangan terbesar yang dihadapi mahasiswa adalah mendapat kepercayaan dari kelompok sasaran karena salah satu output yang diharapkan oleh organisasi pendamping, FOPPERHAM adalah relawan dapat mengembangkan empati dan belajar tentang sejarah dari sumber yang berbeda. Sebaliknya, para ibu

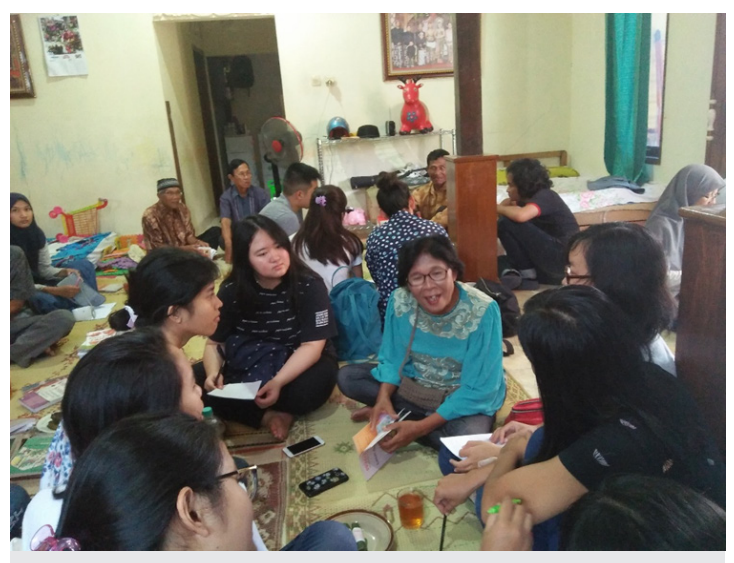

Gambar 5. Berbagi Kisah dalam Pertemuan para Penyintas Peristiwa 1965 yang diprakarsai oleh FOPPERHAM terkadang juga meminta mahasiswa untuk mengajukan pertanyaan-pertanyaan. Aktivitas lainnya adalah mengikuti pertemuan kelompok secara berkala oleh kelompok sasaran yang tidak terbatas pada para ibu, namun juga bapak-bapak lanjut usia dan keluarganya. Temuan penting dari jurnal mahasiswa adalah lahirnya pandangan baru terhadap para penyintas sebagaimana yang ditulis oleh seorang mahasiswi berikut ini.

Saya jadi mengetahui bahwa di dunia ini ternyata segala sesuatu bisa dipalsukan atau ditutup-tutupi dan untuk mengetahui kebenaran, kita harus bertanya kepada mereka yang mengalami secara langsung. Banyak dari mereka adalah cendekiawan, bahkan veteran. Sudah seharusnya mereka mendapatkan kembali hak-hak mereka (Jurnal 13 Mei 2018, mahasiswa FTI-2017). 
Kelompok Sosial Pingit adalah komunitas yang dipilih oleh mahasiswa yang ingin bekerja dengan kelompok anak keluarga miskin di Kota Yogyakarta. Komunitas ini memiliki program kerja yang dirancang agar mahasiswa juga belajar strategi pembelajaran dengan cara bermain. Relawan yang berasal dari berbagai universitas di Yogyakarta mendapat pelatihan pada awal semester dan juga didorong untuk memiliki rencana kegiatan selama satu semester. Kegiatan

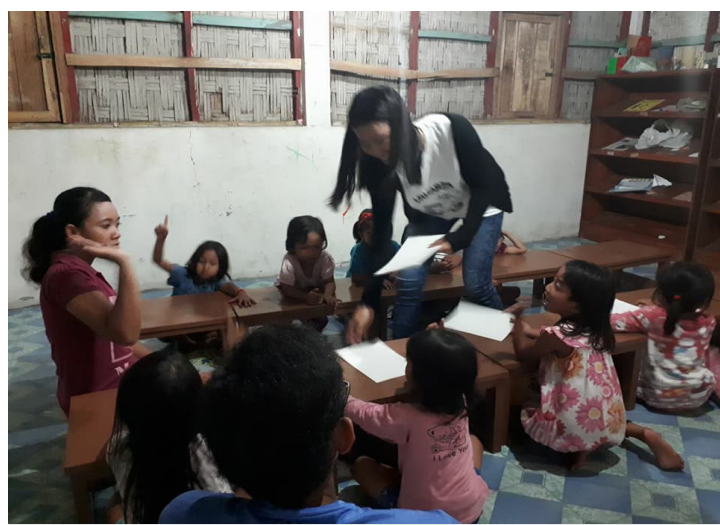

Gambar 6. Kegiatan Mengajar Anak-anak di Komunitas Perkampungan Sosial Pingit rutin dilakukan seminggu dua kali, yakni setiap Senin dan Kamis pada waktu-waktu belajar anak-anak. Komunitas juga membatasi jumlah relawan agar seimbang dengan jumlah anak yang didampingi dengan rasio 1 anak 1 relawan sebagai pendamping. Kegiatan utama adalah mendampingi belajar atau mengerjakan pekerjaan rumah bagi anak-anak usia SD maupun kegiatan bermain bagi anak-anak usia TK. Mahasiswa kadang juga dilibatkan dalam kegiatan kampung bersama kelompok orang tua sehingga kemajuan kegiatan anak-anak dapat dilaporkan melalui kegiatan kampung.

Jurnal mahasiswa memperlihatkan bahwa hal utama yang ditarik dari pengalaman ini adalah menempa disiplin dan belajar tentang perbedaan budaya ketika berelasi dengan anak-anak dan orang tua yang memiliki budaya berbeda dengan mereka, yang kebanyakan merupakan pendatang dari luar Yogyakarta.

Anak-anak di sini sangat aktif dibandingkan dengan anak-anak di daerah asal saya. Saya juga belajar dari komunitas para frater mengapa kami tidak boleh memberi barang apa pun termasuk pensil atau penghapus kepada anak-anak. Saya menjadi lebih kreatif menemukan cara-cara agar anak-anak mau belajar. Mengajar anak-anak ternyata membutuhkan energi yang besar. Saya juga banyak belajar tentang istilah Jawa juga komunikasi cara Jawa karena anak-anak menggunakan bahasa Jawa. Kadang mereka suka mengganggu saya karena saya sering tidak mengerti apa yang mereka katakan (Jurnal April 2017, Mahasiswa FTI-2017).

\section{Penutup}

Dari uraian di atas dapat dipahami apabila service learning dapat digunakan sebagai pendekatan proses pembelajaran yang mengintegrasikan capaian akademik dan pendidikan karakter peserta didik. Pengetahuan dari kelas ataupun dari lapangan serta pengalaman terlibat dalam pemecahan masalah sosial atau lingkungan fisik pada gilirannya memberikan kompetensi sosial-budaya yang melengkapi kompetensi profesional yang diberikan oleh bidang ilmu yang ditekuni oleh peserta didik lulusan perguruan tinggi. Adapun pengaruhnya bagi pengajar adalah meningkatnya keterampilan mengajar, menghubungkan antara materi yang diajarkan di kelas dan realitas yang dihadapi 
masyarakat, serta kebutuhan untuk terus belajar. Jarak antara dunia perguruan tinggi yang dianggap seperti menara gading pun terjembatani sehingga perasaan terabaikan dari masyarakat pun seyogianya sirna.

\section{Daftar Pustaka}

Bridwell. 2013. "Active citizenship, education and service learning" dalam Education, Citizenship and Social Justice 8(2) 185-199.

Fleck, Bethany, Heather D. Hussey, dan Lily Rutledge-Ellison. 2017. "Linking Class and Community: An Investigation of Service" dalam Teaching of Psychology Vol. 44(3) 232-239.

Furco, Andrew .1996. "Service-Learning: A Balanced Approach to Experiential Education" dalam Expanding Boundaries: Serving and Learning. Washington DC: Corporation for National Service, 2-6.

Karl-Heinz, Gerholz, Verena L., dan Katrin B.K. 2018. "Effects of Learning Design Patterns in Service Learning Courses." dalam Active Learning in Higher Education Vol. 19(1) 47-59.

Peraturan Menteri Riset, Teknologi, dan Pendidikan Tinggi Republik Indonesia Nomor 44 Tahun 2015 tentang Standar Nasional Pendidikan Tinggi (pasal 17) ayat 4.

Starting Point Teaching Entry Geoscience, "Why Use Service Learning?" https://serc. carleton.edu/introgeo/service/why.html (diakses pada 1 Mei 2018). 